\title{
Identification of Fungi Associated to Pseudips mexicanus (Curculionidae: Scolytinae) as a Possible Biocontrol Agent
}

\author{
Isaac Tello-Salgado, " , Oscar Burgos-Duenas ${ }^{1}$, Maria Del Rayo Sanchez-Carbente ${ }^{2}$, \\ Armando Burgos-Solorio ${ }^{1}$
}

${ }^{1}$ Biological Research Center, Autonomous University of the State of Morelos, Cuernavaca, Mexico

${ }^{2}$ Biotechnology Research Center, Autonomous University of the State of Morelos, Cuernavaca, Mexico

Email address:

hm_teonanacatl@yahoo.com.mx (I. Tello-Salgado)

${ }^{*}$ Corresponding author

\section{To cite this article:}

Isaac Tello-Salgado, Oscar Burgos-Duenas, Maria Del Rayo Sanchez-Carbente, Armando Burgos-Solorio. Identification of Fungi Associated to Pseudips mexicanus (Curculionidae: Scolytinae) as a Possible Biocontrol Agent. American Journal of Agriculture and Forestry. Vol. 9, No. 4, 2021, pp. 201-210. doi: 10.11648/j.ajaf.20210904.16

Received: June 6, 2021; Accepted: June 23, 2021; Published: July 13, 2021

\begin{abstract}
Entomopathogenic fungi are an important insect biological control group, however most of the fungi described as biological controllers have a broad spectrum of insect hosts. Pseudips mexicanus is a bark beetle that infests pine-oak forests in Mexico, causing significant economic and ecologic losses. In addition, the infestation alters the ecology of different organisms that coexist in the forest habitat. The search for bark beetle control methods other than pesticides has led to research into biological control procedures based on naturally occurring beetle pathogens. The goal of this paper was the isolation, morphological and molecular identification of fungi that naturally parasitize the bark beetle Pseudips mexicanus, as well as to carry out infection tests to propose a specific biological control alternative to this plague. Associated to this beetle, we have identified four isolates belonging to three genus: Beauveria, Lecanicillium and Trichoderma, within these some species have been used previously as biocontrollers, mainly in agricultural use, in the process of transformation of organic crops. The LVP-2 isolated, which was identified as Beauveria was tested for infection of naturally harvested bark beetles and its pathogenicity was proved, at three days post infection (dpi) most of the individuals presented little mobility of the legs and a swelling of the body was noted, however more studies are needed to determine their viability as plague controllers in Mexican forests.
\end{abstract}

Keywords: Bark Beetle, Forest, Pine Trees, Pest Management, Biological Control

\section{Introduction}

In Mexico there are approximately 870 bark beetle species, which are involved in the active degradation of plant biomass [1]. Among the most important bark beetle species that have a major impact in the elimination of large extensions areas of tree forests from North to Central america, are the genus Dendroctonus, Scolytus, Phloeosinus, Ips and Pseudips [2, 3] Particularly the last two genera are present in the North region of Morelos, Mexico [4]. Bark beetles are among the most destructive of the many threats to forest productivity [5]. Bark beetles are insects that inhabit beneath the bark of pine trees; as a consequence, there is damage over tree tissues such as the phloem, important for the sap conduction, causing tree death and massive infestation of other pine trees.
Within the more representative bark beetle species are Dendroctonus frontalis, Dendroctonus adjunctus, Dendroctonus mexicanus, Pseudips mexicanus and Ips spp. $[6,2]$. The last two species are considered secondary bark beetles, meaning that the trees have been colonized previously by other bark beetles' species, usually from the Dendroctonus genus. However, when the populations of secondary bark beetles species increase, then these are considered primary pests that can result in forest tree population loss [3].

Besides the bark insects' importance to the ecosystems balance, such as regulating tree populations as a result of the elimination of burned, sick, stressed or week trees, and recycling of organic matter, they have been also considered "forest pests" [7-11]. In the last years the problems caused by these insects have been growing because of increasing 
numbers in their populations or migration to new areas [12]. The massive infestation of great forest extensions in Mexico's provincial territories including Chihuahua, Durango, Michoacán, Estado de Mexico and Morelos have had detrimental impact in ecological equilibrium as well as in economical aspects. Among the strategies to control bark insects are the use of pruning sanitization, traps with pheromones, use of insecticides among others [13]. Particularly, organochlorine and organophosphate pesticides have been the more conventional method of bark beetle control.

However, the uncontrolled use of these products has brought barker resistance and the pleiotropic elimination of innocuous organism such as bees or butterflies, which play fundamental roles as pollinators, plus the high cost of these chemicals $[14,15]$. Therefore, new strategies to control bark insects have been developed taking in consideration more natural approaches, such is the case of the use of entomopathogenic fungi like Beauveria bassiana, Metarhizium anisopliae (Ascomycota, Hypocreales), or Bacillus thuringiensis among others [16-18]. The use of entomopathogenic fungi as biological control is a regular agricultural and ecological practice that focuses in population reestablishments of insect pests' numbers using their natural controls [19]. This represents an inexpensive and environmental friendly alternative. Furthermore, it may be possible to find biological controls with more specific targets as opposed to the conventional methodologies [20].

The first approach in the characterization of specific biological control microorganisms is the isolation and identification of entomopathogenic fungi infecting bark beetles. The aim of this study was the isolation, as well as morphological and molecular identification of fungi associated with the mortality of $P$. mexicanus in the pine-oak forest in Morelos state, Mexico.

Entomopathogenic fungi are parasitic microorganisms with the ability to infect and kill some arthropods of agricultural interest, they form a monophyletic group, including; Oomycetes, Cytridiomycota, My-crosporidia, Entomophtoromycota, Basidiomycota and more commonly Ascomycota. They are mainly used as biopesticides in organic farming as a safe alternative to toxic chemical insecticides. Mainly species like, Metarhizium, Beauveria and Lecanicillium. In sorghum, tobacco, wheat, soybean, corn, maize, tomato, among others, mainly due to its low toxicity capacity generated from its functional metabolites. $[21,22]$

\section{Materials and Methods}

\subsection{Study Site}

Fungi were isolated from bark beetles collected from Real Montecasino, Morelos, Mexico, located on the west side of the Neovolcanic Transverse Axis, with the following coordinates $19^{\circ} 00^{\prime} 46.58^{\prime \prime} \mathrm{N} 99^{\circ} 15^{\prime} 00.21^{\prime \prime} \mathrm{O}$, Altitude 2329 meters above sea level. The location presents temperatures ranging from 8 to $18^{\circ} \mathrm{C}$, with average annual precipitation of 1000-2000 $\mathrm{mm}$ [21]. The region climate is semi-cold (C (E) (m) (w), C (E) (w2) (w)) and template (C (w2) (w)) according to Köppen system [21, 23]. The location presents pine-oak forests, with Pinus montezumae, Pinus teocote, Pinus pseudostrobus species, among others.

\subsection{Isolation of Fungi}

Fungi isolates were obtained from death bark beetles invading Pseudips mexicanus, that were present in the galleries underneath the bark, showing symptoms of infection (darker color, mycelium or conidiophores growing on the insect cuticle). P. mexicanus guished by length 3.6- $5.0 \mathrm{~mm}$; color dark reddish brown; antenna club with sutures 1 an 2 feebly or very strongly, booadly precurved; pronoto the more coarsely puntured pronotal disc, the puntures moderately coarse, pronotal vetiture finer, apparently les abundant; elitra declivity steep the morphological description is based on Wood's criteria [2]. From the beetles' corpses we took ten sample by striating the cuticle and the sample was placed in petri dishes with Potato Dextrose Agar (PDA) or Malt Extract Agar (MEA) medium for eight days. After this period another sample from the isolates was taken with a sterile bacteriological loop and inoculated onto Petri dishes containing medium with yeast extract, followed of six to eight days of incubation at $28^{\circ} \mathrm{C}$. Once obtained, the isolated fungal strains were morphologically identified using taxonomic keys [24, 25, 26] for each group of the isolated fungi. All cultures used in this study are maintained in the culture collection of the UAEM (Universidad Autónoma del Estado de Morelos).

\subsection{Fungal Morphological Phenotyping}

The fungal species were identified based on the macroscopic and microscopic characteristics using identification keys [24-26] Fungi were identified according to colony morphology using a stereomicroscope $(\times 40$ magnification) and by further mounting slides with the sample of the specimen and observed by light microscopy ( $\times 400$ and $\times 1000$ magnifications, using a Microscope Nikon model Eclipse $80 \mathrm{i}$ and a digital camera Nikon DS-Fi1). The analysis of dichotomus keys such as size, shape and grouping of conidiophores, morphological aspects of the colony and the fungal hyphae were used for the organism identification. Since dilutions were performed until a pure strain was obtained, a single sample for each isolate was used for microscopic observations [24, 27]. Micromorphological identification was completed with an analysis of a region of the ITS2 ribosomal gene sequence for a polyphasic microbial identification [28].

\subsection{Fungal ITS2 rRNA Gene Ribotyping}

For identification, we analyzed molecular markers previously described to be distinctive to filamentous fungi. Regions of the internal transcribed spacers 2 (ITS2) were amplified. The primers and conditions used for these PCR 
reactions have been previously described by White, et al. 1990 [28], respectively. We performed the following protocol: a plate of PDA medium was inoculated with a representative fungal culture and incubated until a reach layer of mycelium was obtained. PCR reactions contained $1 \times$ PCR buffer, $10 \mathrm{ng}$ of fungal DNA, 10 pmol of the forward and reverse primer $2 \mathrm{mM}$ of dNTP's, $1.5 \mathrm{mM}$ of $\mathrm{MgCl}_{2}$, and $1 \mathrm{U}$ of Taq polymerase in a total volume of $20 \mu \mathrm{l}$. The cycling conditions were: $95^{\circ} \mathrm{C}$ for $5 \mathrm{~min}$, followed by 30 cycles of $95^{\circ} \mathrm{C}$ for $30 \mathrm{~s}$., $55^{\circ} \mathrm{C}$ for $30 \mathrm{~s}$ and $72^{\circ} \mathrm{C}$ for $45 \mathrm{~s}$. The PCR products were separated by electrophoresis at $100 \mathrm{~V}$ for 30 min on a $1 \%(\mathrm{w} / \mathrm{v})$ agarose gel in $1 \times$ TAE buffer $(0.4 \mathrm{M}$ Tris, $0.05 \mathrm{M} \mathrm{NaAc}$ and 0.01 M EDTA, pH 7.85) and examined under UV-light [29]. Amplicons were purified from the PCR reactions using a commercial PCR extraction kit (Fermentas Cat. No K0513) and sequenced using the same PCR primers at the Institute of Biotechnology of the UNAM (Universidad Nacional Autónoma de Mexico) in a Terminator Cycle Sequencing Ready Reaction BigDye ${ }^{\circledR}$ terminators v 3.1 (PE Applied Biosystems). The sequencer used was the ABI PRISM Model 3730 Xl genetic analyzer, with data collection software version 3.0. The sequences were analyzed using the online DNA sequence software at the National Center for Biotechnology Information of the National Institutes of Health (NCBI/NIH) website (www.ncbi.nih.gov) using the BLAST similarity search algorithm [30].

\subsection{Phylogeny Reconstruction}

Phylogenetic analysis was performed online with the server Phylogeny.fr (www.phylogeny.fr) [31, 32]. From different sequences retrieved from the BLAST hits, one of each species was used to construct the phylogenetic trees. The sequences were selected according to the sequencing analysis, with respect to the genus obtained from the preliminary analysis of the sequences. In order to deduce the phylogeny of the fungal isolates, ITS sequences were aligned to sequences from related fungi (the same genera) held in Central bureau voor Schimmelcultures (CBS) only where full length sequences were available.

The workflow setting in Phylogeny- fr-included "A la Carte" mode step by step. MUSCLE was used for multiple alignments and they were curated in SeaView software (version 4.6) [33]. BioNJ (Neighbour-Joining) [34] with Kimura 2 Parameters (K2P) [35] was utilized as substitution model. The tree topology was bootstrapped 1000 times. Finally, the graphical visualization was performed by TreeDyn [36]. ITS2-based phylogenies were obtained using BioNJ and K2P as a substitution model, which has been previously used to estimate fungal phylogenetic relationships from ribosomal markers $[37,38]$. The phylogenetic relationship estimation using the BioNJ method and K2P matrix system is a good strategy for robust and high-quality tree constructions based on ribosomal genes [39]. Having said that, phylogenies obtained using BioNJ/K2P have also been employed to establish taxonomic inferences in bacteria [40], fungi [41, 42] and plants [43].

\subsection{Infection Tests on Pseudips Mexicanus}

Bark beetles ( $P$. mexicanus) were collected from a site located on the west side of the Neovolcanic Transverse Axis, with the following coordinates $19^{\circ} 00^{\prime} 0.8^{\prime \prime} \mathrm{N}$ y $99^{\circ} 13^{\prime} 50.7^{\prime \prime} \mathrm{E}$ at 2210 meters above sea level. The insects were on fallen branches of Pinus leiophylla, and transported to the laboratory where they were put on quarantine on disinfected plastic containers (washed with $98 \%$ ethanol) for 20 days to ensure no fungal development showed before inoculation.

The LVP-2 isolate ( $B$. bassiana) was used for the tests chosen by the pathogenicity criterion registered for this species, used for biological control in agricultural crops and was streaked on PDA medium at $25 \pm 2{ }^{\circ} \mathrm{C}$ for 12 days until conidiation occurred. An inoculum of $2.4375 \times 10^{10}$ conidia/g was used to inoculate the beetles after a $30 \mathrm{~S}$ wash with a $0.1 \%$ tween solution in $10 \mathrm{ml}$ of buffer. [44]. Six biological replicates each with ten insects were inoculated. Three biological replicates were left without inoculation as a negative control.

\subsection{Experimental Design and Statistical Analysis of Bioassay}

A survival analysis was performed, which consisted of statistical methods using non-parametric data, using the Kaplan-Meier method calculating the survival of each infected organism, this analysis measures time in intervals and calculates the survival of each interval.

\section{Results}

We obtained 19 samples from $P$. mexicanus corpses that were propagated and subcultured several times to obtain pure isolates (see Figure 1A for an example). We continued with the characterization of four fungal isolates, since those were the more representative according with distinctive colony morphology. These isolates were named LPV-2 to 5 that stands for Laboratorio de Parasitología Vegetal.

Once isolated, the fungi were identified by morphological and molecular criteria to the species level. Only three fungal genera were found in four isolates: Lecanicillium (1) (Clavicipitaceae), Trichoderma (2) (Hipocreaceae), and Beauveria (1) (Clavicipitaceae).

\subsection{Morphological Description of the Isolates}

\subsubsection{Isolate LPV-2 (Beauveria bassiana)}

The colonies of this isolate had a diameter of 10-16 mm after 1 week of growth, these were woolly with dust like shape due to abundant conidia. In the initial growth the colony was white but it turned yellow in PDA medium (Figure 1B). Occasionally the conidial apparatus was clustered; more often the conidiogenous cells were arranged in small groups or solitarily along the hyphae. Conidiogenous cells were observed consisting of a subglobose or flaskshaped, sometimes subcylindrical in the basal part with the following measurements in our sample (3-) 4-15 (-28) $\times(1.5-$ ) $2-3.5(-4) \mu \mathrm{m}$, and a well developed rachis, up to $25 \mu \mathrm{m}$ 
long and mostly 1-1.5 $\mu \mathrm{m}$ wide. Conidia were hyaline, smooth, ellipsoidal (rarely subglobose), widest near or below the middle, sometimes with a pointed or apiculate base, (2-)
2.5-4.5 (-6) × (1.5-) 2-2.5 (-3) $\mu \mathrm{m}$. These observations are coincident with the morphological description assigned to Beauveria genus [45] (Figure 1C).

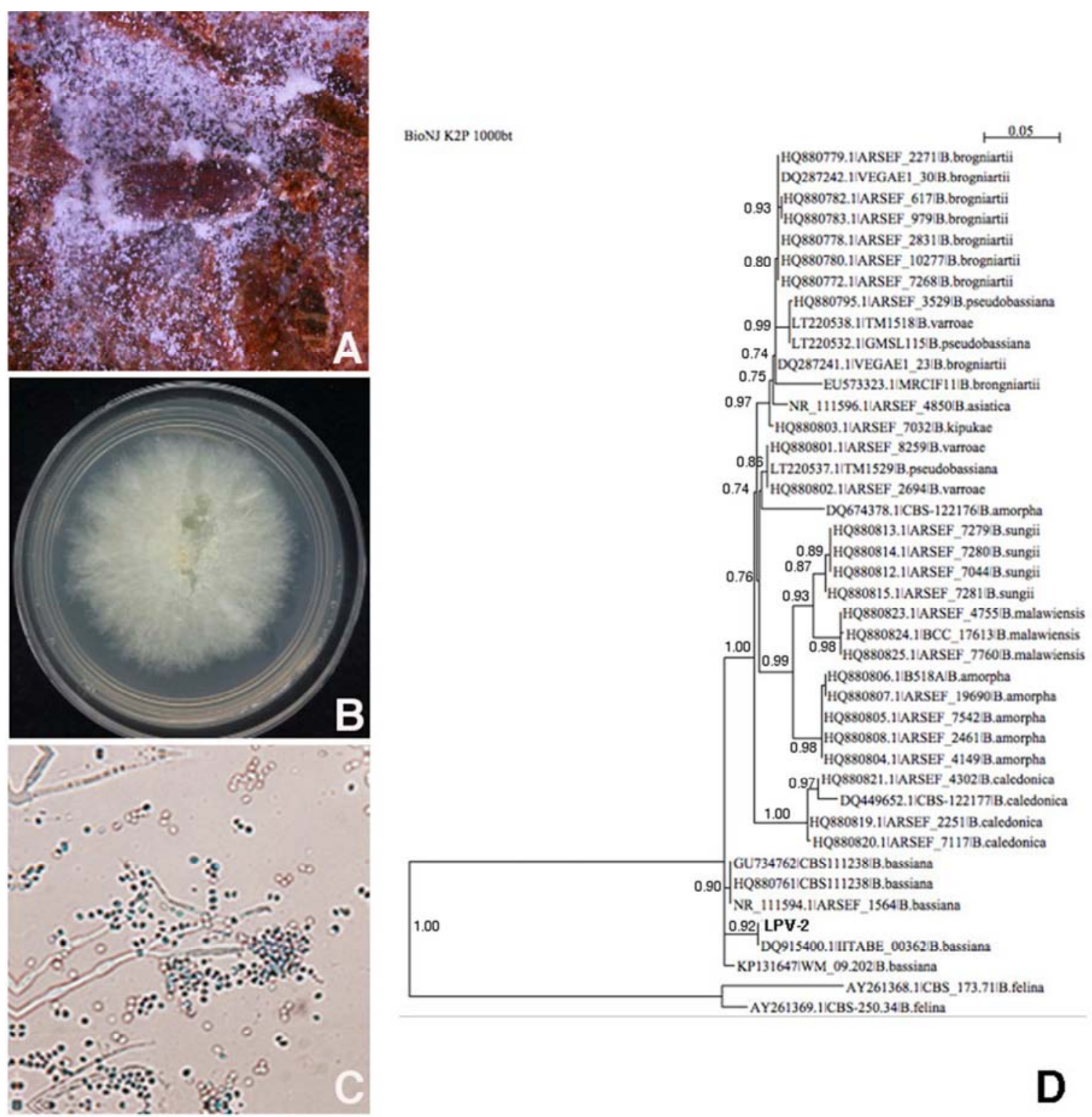

Figure 1. Colony morphology of LPV-2 fungi isolated from bark beetle Pseudips mexicanus. A) Bark beetle corpse from where strain LPV-2 was isolated. B) Colony morphology of the LPV-2 isolate. C) Conidia of isolate LVP-2. D) Phylogenetic reconstruction for strain LVP-2. ITS2 sequences for LPV2 were deposited in NCBI under accession number KY432692.

\subsubsection{Isolate LPV-3 (Lecanicillium Aphanocladii)}

Isolate LPV-3 grew similarly on two cultivation media (PDA and MEA) forming white and deeply woolly colonies, yellow pigmentation was observed which was timedepending, starting from the 7 th day of cultivation at $25^{\circ} \mathrm{C}$ in the dark and on dependency on the medium composition (Figure 2A). The culture medium influences also the intensity of conidia formation (data not shown). This fungus turned media to a reddish color, a characteristic that has been reported for L. aphanocladii Zare \& W. Grams [46]. The mycelium is septated and the aphanophialides were scattered or in verticillium with variable size with range of $12-40 \times$
$0,8-3,0 \mu \mathrm{m}$. In our samples, the conidia are cylinders with the following measurements: $2-10 \times 1,0-2,6 \mu \mathrm{m}$, which could be present in groups and without presence of chlamydospores. The fungus formed short, basally swollen, with narrow tip, rapidly collapsing into inconspicuous denticles conidiophores (aphanophialides in the sense of Gams, 1971) [47], which bear single ellipsoidal conidia; aphanophialides scattered laterally along the procumbent or prostrate aerial hyphae. The mycelium was septated, presenting verticilate or solitary phialides with variable size between $12-40 \times 0,8-3,0 \mu \mathrm{m}$. According to [27], the morphological analysis of colonies suggests that the microorganism is from the genus Lecanicillium (Figure 2B). 


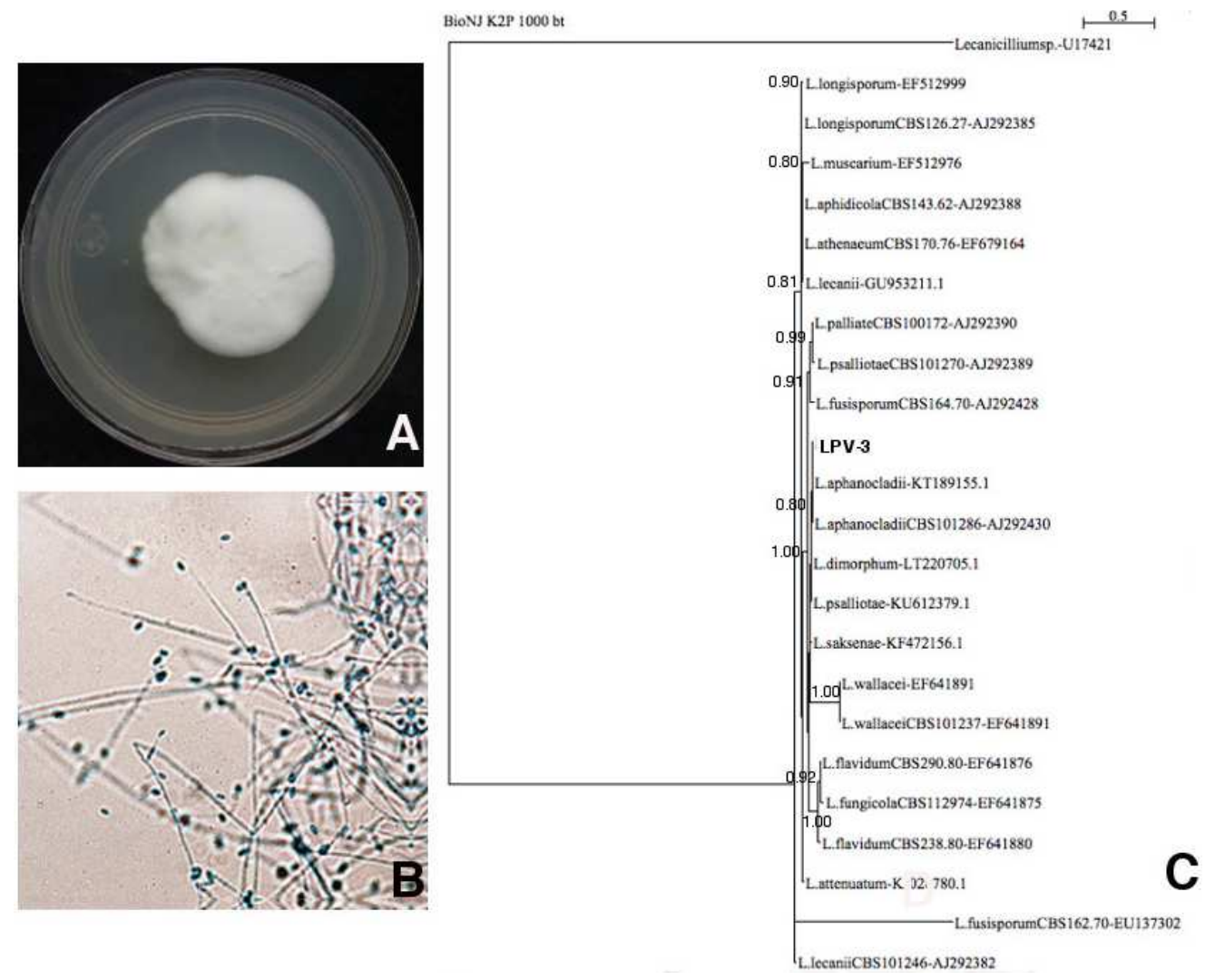

Figure 2. Characteristics for strain LVP-3. A) Colony morphology of the LPV-3 isolate. B) Conidia of isolate LVP-3. D) Phylogenetic reconstruction for strain LVP-3. ITS2 sequences for LPV3 were deposited in NCBI under accession number KY433313.
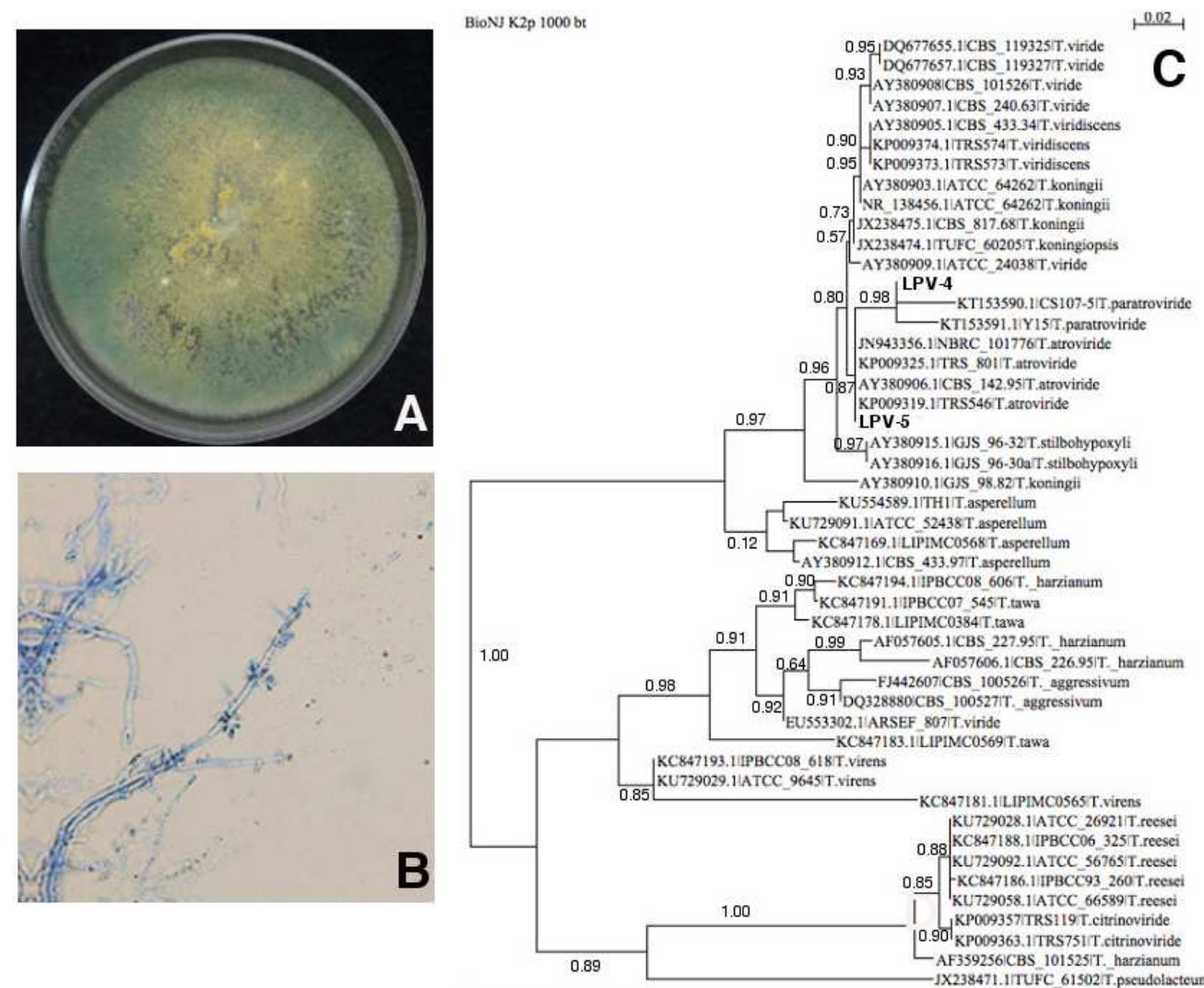

Figure 3. Characteristics for strain LVP-4. A) Colony morphology of the LPV-4 isolate. B) Conidia of isolate LVP-4, C) Phylogenetic reconstruction for strains LVP-4 and 5. ITS2 sequences for LPV4 and LPV5 were deposited in NCBI under accession numbers KY433314 and KY433315. 


\subsubsection{Isolates LPV-4 and LPV5 (Trichoderma}

Paratroviride and T. Atroviride, Respectively)

Other fungi obtained from the beetle presented the following morphology: they grew forming concentric rings (Figure 3A), with septated a hyaline hyphae and the following measurements in our sample: intricate conidiophores with 50.0-60.0 $\times$ 2.0-3.0 $\mu \mathrm{m}$, forming verticillium with five phialides ampule shaped with dimensions of $10.5 \times 3.3 \mu \mathrm{m}$ and $2.2 \mu \mathrm{m}$ to the base. They did not present intercalated phialides. Conidia were globose to subglobose, with smooth walls and green olive color, ranging in size of $(3.5 \times 3.1) \mu \mathrm{m}$. The characteristics of this isolates were in accordance to the description given by [22] for the genus Trichoderma (Figure 3B).

\subsection{Phylogenetic Analysis}

A first phylogeny was constructed with the three isolates that allowed us to situate the fungi with their respective genera confirming the morphological identification (Figure 4). Also this tree indicated the probable species to which the isolates belonged. To confirm this, more refined trees were constructed for each isolate using specific sequences of wellidentified fungi from databases. (Figures 1D, 2C and 3C).

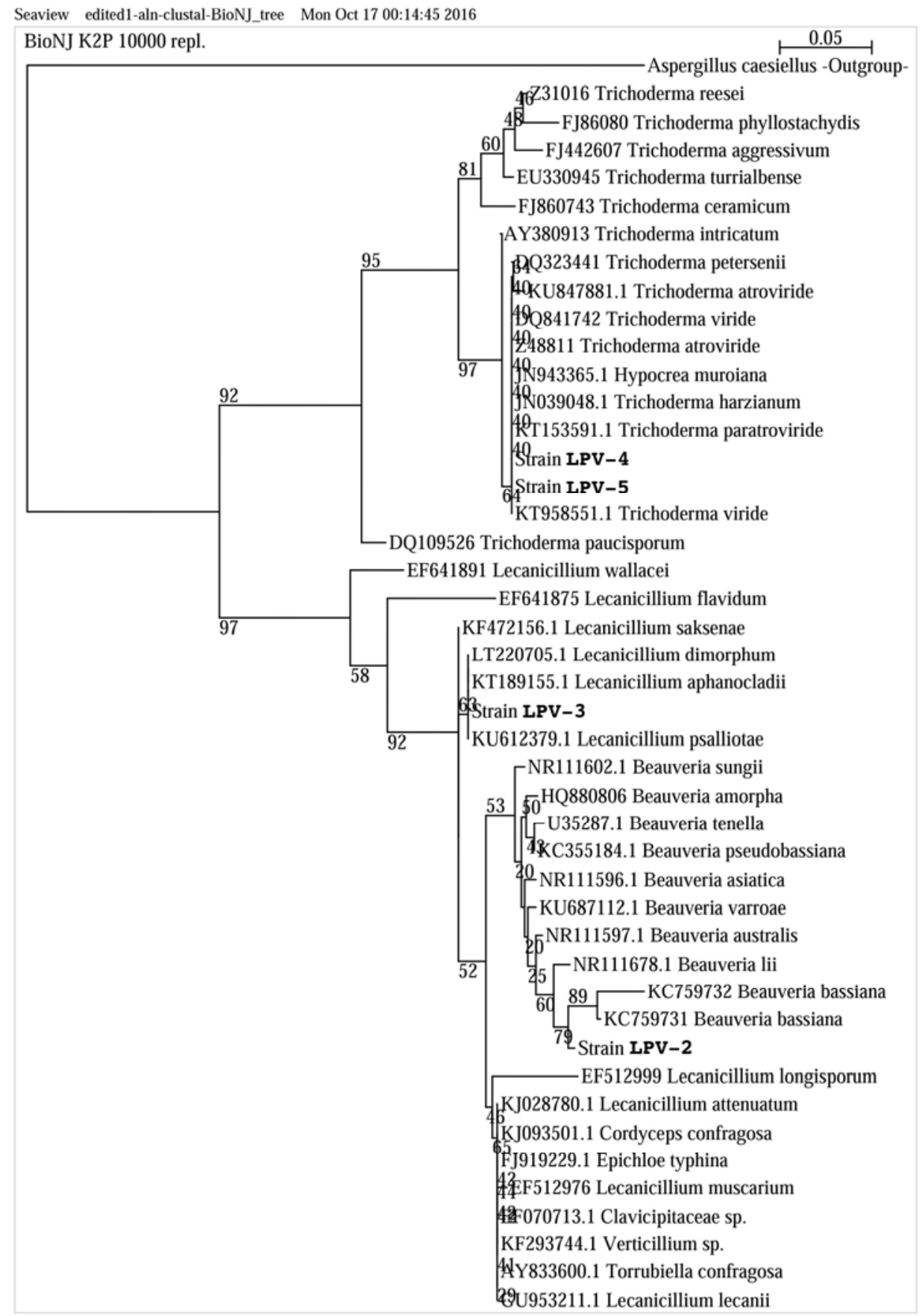

Figure 4. Phylogenetic Tree for the four Isolates from Pseudips mexicanus. The phylogeny was obtained using BioNJ and K2P as a substitution model. 
Strain LPV-2 was clustered with Beauveria species, being B. bassianna grouped in exactly the same position as other B. bassianna species, confirming its identity. A high bootstrap value $(92 \%)$ supports this result (Figure 1D).

Strain LPV-3 was grouped with Lecanicillium genera, being L. aphanocladii the most phylogenetically related species, grouping in the same position with reference species, thus allowing its identification. Bootstrap values strongly support our identification (80\%) (Figure 2C).

Regarding the tree topology of strains LPV-4 and LPV-5, they were clustered with Trichoderma paratroviride and $\mathrm{T}$. atroviride, respectively. This clade showed a strong support (97\% branch support) all the Trichoderma's clade shows high bootstrap values indicating the robustness of the tree (Figure 3C).

Finally, these results are consistent with the morphological classification for these four fungal isolates.

\subsection{Infection of Bark Beetles by Isolate LVP-2}

After 24 hours the experimental population showed a little lethargy. Two days post infection (dpi) lethargy was evident in most of the individuals and the treated insects showed clumsy movements. At three dpi most of the individuals presented little mobility of the legs and a swelling of the body was noted. At four dpi, inflammation of the abdomen was evident and the intersegment unions were slightly separated. At five dpi, none of the individuals moved and from six to seven dpi a mucilaginous secretion was observed in the intersegment unions between the thorax and the abdomen. At 12 dpi mycelia covered completely the body of the bark beetles, all treated individuals died after six days of infection with LPV-2 isolate. $(100 \%$ of the treated individuals). The control insects did not show this behavior, only a few of them died (16\%) (Table 1) and none of them developed mycelial growth. Conidia recovered from the dead infected bark beetles were identical to those initially described for this isolate.

Table 1. Mortality percentage of individuals treated or untreated with LPV-2 isolate (B. bassiana) at different days' post inoculation (Dpi) Letters indicate statistical significance using an ANOVA test.

Table 1. Percentage of mortality of Pseudips mexicanus.

\begin{tabular}{lll}
\hline \multirow{2}{*}{ Time (Days) } & \multicolumn{2}{l}{ \% of mortality of Pseudips mexicanus } \\
\cline { 2 - 3 } & Infected & Non-infected \\
\hline 1 & $0( \pm 0.0)$ & $0( \pm 0.0)$ \\
2 & $6.66( \pm 5.77)^{\mathrm{e}}$ & $0( \pm 0.0)$ \\
3 & $16.66( \pm 5.77)^{\mathrm{d}}$ & $0( \pm 0.0)$ \\
4 & $36.66( \pm 5.77)^{\mathrm{c}}$ & $0( \pm 0.0)$ \\
5 & $66.66( \pm 5.77)^{\mathrm{b}}$ & $0( \pm 0.0)$ \\
6 & $100( \pm 0.0)^{\mathrm{a}}$ & $6.66( \pm 5.77)^{\mathrm{e}}$ \\
7 & $100( \pm 0.0)^{\mathrm{a}}$ & $16.66( \pm 5.77)^{\mathrm{d}}$ \\
\hline
\end{tabular}

\section{Discussion}

The bark beetles, specially the genus Ips and the species Pseudips mexicanus, are considered "forest pests" that cause major economic losses and ecologic alterations in Mexico and other countries such as Canada, USA and some European countries [48, 49]. Fungi associated with to bark beetles represent a potential to develop specific strategies of biological control. For example, it has been described that the anamorphic taxa B. bassiana and M. anisopliae, (Hypocreale, Ascomycota), are among the natural enemies of pests, such as; Hypothenemus hampei, Helicoverpa zea, Aphis gossypii and Ostrinia nubilalis. [50-53]. Both are natural enemies of a wide range of insects and arachnids particularly in agriculture, however less is known about their relevance in forest ecosystems [54, 59]. In this work we showed morphologically and phylogenetically that an isolate of $B$. bassiana obtained from a bark beetle corpses was capable of acting as an entomopathogenic agent on $P$. mexicanus, killing the insects in only six days. To the best of our knowledge this is the first report of a $B$. bassiana strain that infects $P$. mexicanus and could represent a potential biocontrol to this pest in pine forests. However, previously [55], report the isolation of $B$. bassiana was previously reported to be isolated from Ips sexdentatus and Ips typographus both collected from Austria. Also, it has been reported the use of $B$. bassiana, M. anisopliae to control bark beetles of the genus Ips, particularly species such as I. typogrpahus, I. sexdentatus, Ips grandicollis and Ips calligraphus mostly in Europe, however those strains were from commercial sources [56-59].

Furthermore, other fungi such as genera Lecanicillium, Paelomyces, and Nomurae rileyi have been reported to control aphids and other pests [60]; however most of these reports focused the attention to agroeconomic important pests.

In this paper, we also report the presence of different fungi belonging to distinct genera which were found present in association with bark beetles' corpses that have not been studied in such detail as other genera as Beauveria or Metharizium: Lecanicillium aphanocladii and Trichoderma paratroviride and atroviride. The fact that these fungi were isolated from bark beetle corpses found inside tree galleries and showed other symptoms of sickness such as darker color and mycelia emerging from the inside of the body, suggests their pathogenic activity in those insect. Experiments are under way to test their infection capabilities. Furthermore, these genera have been reported to be entomopathogens for other invertebrate orders such as Lepidoptera, diptera as well as nematodes (see below). To the best of our knowledge, this is the first report in Mexico of the association of these entomopathogenic fungi with a bark beetle. In 2014, [61] showed the efficient use of Trichoderma harzianum as biological control for Aedes aegypti, reporting a $96 \%$ of mortality. There are also recent reports of Trichoderma hamatum that infect aphids [62]. Nevertheless, we have found no reports of any Trichoderma species infecting Ips or Pseudips Bark beetles, which would be a novel and interesting finding, especially because $T$. atroviride has proven to be also a mycoparasite [63] and has the ability to 
colonize the roots of certain plants [64], features that would enhance its environmental potential as a biocontroller.

Lecanicillium spp. has been used as biological control against dipters, such as $A$. aegypti, the carrier of the malaria parasite, and some mites with impact in human health. For example, [65] identified adult mosquitoes of A. aegypti, Anopheles arabiensis and Culex quinquefasciatus naturally infected with Lecanicillium [65]. The use of these fungi as biological controllers shows high efficiency since the mortality of mosquitoes reaches the $87 \%$. From these results a trap methodology has been established to inoculate domestic mosquitoes and control their populations. We have also not found any report of any Lecanicillium species infecting bark beetles. Our findings thus open a new perspective to study this genus to apply these fungi as biocontrollers for forest plagues.

An effective biocontrol strategy against bark beetles of forest importance requires the selection of fungal isolates that combine desirable characteristics such as pathogenicity and conidia production to control the bark beetles, in particular $P$. mexicanus.

This study proposes the bases to develop proper strategies to control and manage of forest important pests in Mexico, as is $P$. mexicanus.

\section{Conclusion}

The alternative to control bark insects with entomopathogenic organisms is essential, since today agrochemicals are not specific and harm beneficial organisms for crops. The control Biological is a viable alternative for the control of barking insects of forest importance, since that these may be specific to certain pests.

A correct identification of pest control organisms isolated from specific and natural environments is essential to design strategies to reduce the damage caused by pest insects. Modern biotechnological identification methods combined with classical identification methods lead to correct identification, which is useful to obtain genetic resources with unique properties.

The biological tests carried out with Pseudips mexicanus using the fungus $B$. bassiana, presented a high mortality in a time of 96 to 120 hours, which is essential for the control of insects of forest importance. In the tests carried out, it was found that the control method for debarkers is appropriate for a good integrated pest management.

\section{Funding}

This work was partially founded by CONACyT grant number 250831 and grant SEP-PRODEP UAEM-PTC-333. PRODEP DSA/103.5/15/6986.

\section{Conflict of Interest}

The authors declare that they have no conflict of interest and we agree to the publication of these results.

\section{References}

[1] Atkinson, T. H. (2012) State of knowledge of the taxonomy of the bark and ambrosial beetles of Mexico (Coleoptera: Curculionidae: Scolytinae). Memory of the XVI National Symposium on Forest Parasitology. 1: 13-27.

[2] Wood, S. L. (1982). The bark and ambrosia beetles of North and Central America (Coleoptera: Scolytidae), a taxonomic monograph. Great Basin Naturalist Memoirs 6: 1-1356.

[3] Cibrián, T. J., and Cibrián, T. D. (1998). Las plagas y enfermedades de los bosques de México. Ciclo Conf. El Sect. For. México Av. Perspect. Mem. México, D. F. 19-23.

[4] Camacho-Pantoja A. (2012) El género Ips (Coleóptera: Curculionidae: Scolytinae) en México. Tesis doctoral. Colegio de Postgraduados, Chapingo. 1-73.

[5] Goheen, D. J., and Hansen, E. M. (1993). Effects of pathogens and bark beetles on forests. 175 .

[6] Hernández Paz, M. (1975). El Gorgojo de la Corteza, Plaga Principal de los Pinares; Dendroctonus frontalis Zimm (Coleooptera: scolytidae). Publ. 1 P1, 1-3.

[7] Harmon, M. E., Swanson, F. J., H., Franklin, J. M., Gregory S. V., Lattin, J. D., Anderson S. P., and Cummins, K. W. (1986). Ecology of coarse woody debris in temperate ecosystems.

[8] Carpenter SE, Harmon ME, Ingham ER, Kelsey RG, Lattin JD, Schowalter TD. (1988) Early paterns of heterotroph activity in conifer logs. Proc R Soc Edinb Sect B Biol Sci 94, 33-43.

[9] Edmonds, R. L., and Eglitis, A. (1989). The role of the Douglas-fir beetle and wood borers in the decomposition of and nutrient release from Douglas-fir logs. Can. J. For. Res. $19,853-859$.

[10] Zhong, H., and Schowalter, T. D. (1989). Conifer bole utilization by wood-boring beetles in western Oregon. Can. J. For. Res. 19, 943-947.

[11] Schowalter, T. D., and Filip, G. M. (1993). Bark beetlepathogen-conifer interactions: an overview. Beetle-Pathog. Interact. Conifer For. Ed. TD Schowalter GM Filip Acad. Press Inc San Diego CA 4.

[12] Wong, C. M. and Daniels, L. D. (2016) Novel forest decline triggered by multiple interactions among climate, an introduced pathogen and bark beetles. Glob Chang Biol. doi: $10.1111 /$ gcb. 13554 .

[13] Atkinson, T. H., Saucedo, C. E., Martínez, E., and Burgos, A. (1986). Coleópteros Scolytidae y Platypodidae asociados con las comunidades vegetales de clima templado y frío en el estado de Morelos, México. Acta Zool. Mex. Ns 17, 1-58.

[14] Birch, M. C., Haynes, K. F., and others (1982). Insect pheromones. Studies in Biology No. 147. Edward Arnold Ltd., $60 \mathrm{p}$.

[15] Llanderal, C. C. (2000). Introducción a la fisiología de insectos. Colegio de Post-Graduados, Chapingo, México. 1-29.

[16] Butt, T. M., Jackson, C., and Magan, N. (2001) Introductionfungal biological control agents: Progress, problems and potential, in Fungal Biocontrol Agents: Progress, Problems and Potential, edited by TM Butt, C. Jackson N Morgan CAB Int. Wallingford UK 1-8. 
[17] Fonseca A. G. (2008). Distribución Espacial de Pseudohylesinus variegatus y Pityophthorus elatinus asociados Abies religiosa, en el Parque Nacional Lagunas de Zempoala.

[18] Hajek, A. E., and Bauer, L. S. (2009). Use of entomopathogens against invasive wood boring beetles in North America. In Use of Microbes for Control and Eradication of Invasive Arthropods, (Springer), pp. 159-179.

[19] Spadaro, D., and Gullino, M. L. (2004). State of the art and future prospects of the biological control of postharvest fruit diseases. Int. J. Food Microbiol. 91, 185-194.

[20] Summy, K. R., and French, J. V. (1988). Biological control of agricultural pests: concepts every producer should understand. J. Rio Gd. Val. Hortic. Soc. USA.

[21] Anna Litwin, Monika Nowak, Sylwia Różalska. 2020. Entomopathogenic fungi: unconventional applications. Rev. Environ Sci. Biotechnol. 19: 23-42.

[22] Spiridom Mantzoukas and Panagiotis A. Eliopoulos. (2020). Endophytic entomopathogenic fungi: A valuable biological control tool against plant pests. Appl. Sci. 10, 360.

[23] INEGI, 2016

www.inegi.org.mx/inegi/conacyt/doc/proyectos/uam.zip\#UA M/TERCERA20ETAPA/Informe\%20de\%201a\%20Tercera\%2 0Etapa\%20del\%20Proyecto\%20187311.pdf

[24] Barnett, H. L., and Hunter, B. B. (1972). Illustrated genera of imperfect fungi (JSTOR).

[25] Webster J. 1986. Introduction to Fungi. 2o ed. Cambridge University Press.

[26] Domsch, K. H., W. Gams and T. Anderson. 1993. Compendium of soil fungi. IHV-Verlag, $859 \mathrm{pp}$.

[27] Domsch, K. H., Gams, W., and Anderson, T. (1980). Compedium of soil fungi. Vol. I (Academic Press, London).

[28] White, T. J., T. D. Bruns, S. B. Lee, and J. W. Taylor. 1990. Amplification and direct sequencing of fungal ribosomal RNA genes for phylogenetics. Pp. 315-321. In: PCR protocoh: A guide to methods and applications. Eds., M. A. Innis, D. H. Gelfand. J. J. Sninsky, and T. J. White. Academic Press, New York.

[29] Sambrook, J., and Russel, D. W. (2001). Molecular Cloning: a laboratory manual, Cold Spring Harbour Laboratory Press (Cold Spring Harbour).

[30] Altschul, S. F., Madden, T. L., Schäffer, A. A., Zhang, J., Zhang, Z., Miller, W., and Lipman, D. J. (1997). Gapped BLAST and PSI-BLAST: a new generation of protein database search programs. Nucleic Acids Res. 25, 3389-3402.

[31] Dereeper, A., Guignon, V., Blanc, G., Audic, S., Buffet, S., Chevenet, F., Dufayard, J.-F., Guindon, S., Lefort, V., Lescot, M., Claverie, J. M., and Gascuel, O. (2008). Phylogeny. fr: robust phylogenetic analysis for the non-specialist. Nucleic Acids Res. 36, W465-469.

[32] Dereeper, A., Audic, S., Claverie, J.-M., and Blanc, G. (2010). BLAST-EXPLORER helps you building datasets for phylogenetic analysis. BMC Evol. Biol. 10, 8.

[33] Gouy, M., Guindon, S., and Gascuel, O. (2010). SeaView version 4: A multiplatform graphical user interface for sequence alignment and phylogenetic tree building. Mol. Biol. Evol. 27, 221-224.

[34] Gascuel, O. (1997). BIONJ: an improved version of the NJ algorithm based on a simple model of sequence data. Mol. Biol. Evol. 14, 685-695.

[35] Kimura, M. (1980). A simple method for estimating evolutionary rates of base substitutions through comparative studies of nucleotide sequences. J. Mol. Evol. 16, 111-120.

[36] Chevenet, F., Brun, C., Bañuls, A.-L., Jacq, B., and Christen, R. (2006). TreeDyn: towards dynamic graphics and annotations for analyses of trees. BMC Bioinformatics 7, 439.

[37] Paul, N. C., Lee, H. B., Lee, J. H., Shin, K. S., Ryu, T. H., Kwon, H. R., Kim, Y. K., Youn, Y. N., and Yu, S. H. (2014). Endophytic Fungi from Lycium chinense mill and characterization of two new Korean records of Colletotrichum. Int. J. Mol. Sci. 15, 15272-15286.

[38] Sun, S., Zeng, X., Zhang, D., and Guo, S. (2015). Diverse fungi associated with partial irregular heartwood of Dalbergia odorifera. Sci. Rep. 5.

[39] Spicer, G. S., and Bell, C. D. (2002). Molecular Phylogeny of the Drosophila virilis Species Group (Diptera: Drosophilidae) Inferred from Mitochondrial $12 \mathrm{~S}$ and 16S Ribosomal RNA Genes. Ann. Entomol. Soc. Am. 95, 156-161.

[40] Marcheggiani, S., Iaconelli, M., D'angelo, A., Pierdominici, E., La Rosa, G., Muscillo, M., Equestre, M., and Mancini, L. (2008). Microbiological and 16S rRNA analysis of sulphitereducing clostridia from river sediments in central Italy. BMC Microbiol. 8, 171.

[41] Ernst, M., Neubert, K., Mendgen, K. W., and Wirsel, S. G. R. (2011). Niche differentiation of two sympatric species of Microdochium colonizing the roots of common reed. BMC Microbiol. 11, 242.

[42] Rimington, W. R., Pressel, S., Duckett, J. G., and Bidartondo, M. I. (2015). Fungal associations of basal vascular plants: reopening a closed book? New Phytol. 205, 1394-1398.

[43] Yang, X., Cheng, Y.-F., Deng, C., Ma, Y., Wang, Z.-W., Chen, X.-H., and Xue, L.-B. (2014). Comparative transcriptome analysis of eggplant (Solanum melongena L.) and turkey berry (Solanum torvum $S w$.): phylogenomics and disease resistance analysis. BMC 488 Genomics 15, 412.

[44] Fuentes, C. C., Blanco, C. J. L. 2007. Los postulados de koch revisión y perspectiva actual. Revista complutense de ciencias veterinarias. Vol. 1 (2). pág. 262-266.

[45] Rehner, S. A., Minnis, A. M., Sung, G. H., Luangsa-ard, J. J., Devotto, L., \& Humber, R. A. (2011). Phylogeny and systematics of the anamorphic, entomopathogenic genus Beauveria. Mycologia, 103 (5), 1055-1073.

[46] Pečiulytè, D., and Kačergius, A. (2012). Lecanicillium aphanocladii-a new species to the mycoflora of Lithuania and a new pathogen of tree leaves mining insects. Botanica Lithuanica, 18 (2), 133-146.

[47] Zare, R., and Gams, W. (2004). A monograph of Verticillium section Prostrata (Plant Pests and Diseases Research Institute).

[48] Comisión Nacional Forestal Coordinación General de Conservación y Restauración 364 Gerencia de Sanidad Forestal (2010). Manual de Sanidad Forestal. 
[49] Hajek, A. E., Bauer, L. S., and Har (2007). Microbial control of wood-boring insects attacking forest and shade trees. In Field Manual of Techniques in Invertebrate Pathology, (Springer), pp. 505-525.

[50] Vega, F. E.; Posada, F.; Aime, M. C.; Pava-Ripoll, M.; Infante, F.; Rehner, S. A. Entomopathogenic fungal endophytes. Biol. Control 2008, 46, 72-82.

[51] Powell, W. A.; Klingeman, W. E.; Ownley, B. H.; Gwinn, K. D. Evidence of endophytic Beauveria bassiana in seed-treated tomato plants acting as a systemic entomopathogen to larval Helicoverpa zea (Lepidoptera: Noctuidae). J. Entomol. Sci. 2009, 44, 391-396.

[52] González-Mas, N.; Cuenca-Medina, M.; Gutiérrez-Sánchez, F.; Quesada-Moraga, E. Bottom-up e_ects of endophytic Beauveria bassiana on multitrophic interactions between the cotton aphid, Aphis gossypii, and its natural enemies in melon. J. Pest. Sci. 2019, 92, 1271-1281.

[53] Bing, L. A.; Lewis, L. C. Suppression of Ostrinia nubilalis (Hübner) (Lepidoptera: Pyralidae) by endophytic Beauveria bassiana (Balsamo) Vuillemin. Environ. Entomol. 1991, 20, 1207-1211.

[54] Meyling, N. V., and Eilenberg, J. (2007). Ecology of the entomopathogenic fungi Beauveria bassiana and Metarhizium anisopliae in temperate agroecosystems: potential for conservation biological control. Biol. Control 43, 145-155.

[55] Steinwender, B. M., Krenn, H. W., and Wegensteiner, R. (2010). Different effects of the insectpathogenic fungus Beauveria bassiana (Deuteromycota) on the bark beetle Ips sexdentatus (Coleoptera: Curculionidae) and on its predator Thanasimus formicarius (Coleoptera: Cleridae). J. Plant Dis. Prot. 117, 33-38.

[56] Vaupel, O., and Zimmermann, G. (1996). Orientierende Versuche zur Kombination von Pheromonfallen mit dem insektenpathogenen Pilz Beauveria bassiana (Bals.) Vuill. Gegen die Borkenkaferartlps typographus L. (Col., Scolytidae). Anz. Für Schädlingskunde Pflanzenschutz Umweltschutz 69, 175-179.

[57] Kreutz, J., Zimmermann, G., Marohn, H., Vaupel, O., Mosbacher, G., and others (2000). Preliminary investigations on the use of Beauveria bassiana (Bals.) Vuill. and other control methods against the bark beetle Ips typographus (Col.,
Scolytidae) in the field. Mitteilungen Dtsch. Ges. Für Allg. Angew. Entomol. 12, 119-125.

[58] Kirisits, T. (2010). Fungi isolated from Picea abies infested by the bark beetle Ips typographus in the Biallowieza forest in north-eastern Poland. For. Pathol. 40, 100-110.

[59] Mudronceková, S., Mazán, M., Nemcovic, M., and Salamon, I. (2013). Entomopathogenic fungus species Beauveria bassiana (bals.) and Metarhizium anisopliae (metsch.) used as mycoinsecticide effective in biological control of Ips typographus (L.). J. Microbiol. Biotechnol. Food Sci. 2, 2469.

[60] Vu, V. H., Hong, S. I., and Kim, K. (2008). Production of aerial conidia of Lecanicillium lecanii 41185 by solid-state fermentation for use as a mycoinsecticide. Mycobiology 36, 183-189.

[61] Sundaravadivelan, C., and Padmanabhan, M. N. (2014). Effect of mycosynthesized silver nanoparticles from filtrate of Trichoderma harzianum against larvae and pupa of dengue vector Aedes aegypti. L. Environ. Sci. Pollut. Res. 21, 4624 4633.

[62] Mona Khaleil, El-Mougith, Abdou, Hashem, Halim and Lokma Noha (2016). Biocontrol Potential of Entomopathogenic Fungus, Trichoderma hamatum against the Cotton Aphid, Aphis gossypii. IOSR Journal of Environmental Science, Toxicology and Food Technology (IOSR-JESTFT) eISSN: 2319-2402, p-ISSN: 2319-2399. Volume 10, Issue 5 Ver. II (May. 2016), PP 11-2.

[63] Brotman, Y., Gupta Kapuganti J., Viterbo A. (2010) Trichoderma. Current Biology, Volume 20, Issue 9, 11 May, Pages R390-R391.

[64] Salas-Marina M. A., Silva-Flores M. A., Uresti-Rivera E. E, Castro-Longoria E, Herrera- Estrella A and Sergio CasasFlores. (2011) Colonization of Arabidopsis roots by Trichoderma atroviride promotes growth and enhances systemic disease resistance through jasmonic acid/ethylene and salicylic acid pathways. European journal of plant pathology 131 (1): 15-26.

[65] Luz, C., Mnyone, L. L., Sangusangu, R., Lyimo, I. N., Rocha, L. F., Humber, R. A., and Russell, T. L. (2010). A new resting trap to sample fungus-infected mosquitoes, and the pathogenicity of Lecanicillium muscarium to culicid adults. Acta Trop. 116, 105-107. 